\title{
Edukasi Perilaku Hidup Bersih Dan Sehat (PHBS) Di Masa Adaptasi Kebiasaan Baru Di Kelurahan Kampung Baru Kota Sorong
}

\author{
Wahyuni Maria Prasetyo Hutomo*1, Irfandi Rahman², Evi Hudriyah Hukom³, Merlis Simon ${ }^{4}$ \\ 1,2,3,4Program Studi Ilmu Keperawatan, STIKES PAPUA, Indonesia \\ *e-mail: yunihutomo92@gmail.com ${ }^{1}$,irfandirahman477@gmail.com ${ }^{2} \underline{\text { evihudriyahhukom@gmail.com }}^{3}$ \\ merlis.simon04@gmail.com ${ }^{4}$
}

\begin{abstract}
Abstrak
Perilaku hidup bersih dan sehat atau PHBS adalah upaya untuk memperkuat budaya seseorang, kelompok maupun masyarakat agar peduli dan mengutamakan kesehatan untuk mewujudkan kehidupan yang lebih berkualitas. Dalam usaha pencegahan penyebaran pandemi Covid-19 ini, Masyarakat memiliki peran yang sangat penting. Kelurahan Kampung Baru merupakan bagian dari wilayah kerja Puskesmas Malawei di Kota Sorong yang wilayahnya memiliki pasien positif Covid-19. Dari laporan Dinas Kesehatan Propensi Papua Barat, wilayah kerja Puskesmas Malawei Kota Sorong terdapat 26 Kasus COVID-19 yang terkonfirmasi positif dengan 1 orang meninggal Berdasarkan hal tersebut maka Kami melakukan Pengabdian di kelurahan kampung baru kota sorong dengan Tujuan memberikan edukasi perilaku hidup dan sehat (PHBS) di masa adaptasi kebiasaan baru di kelurahan kampung baru kota sorong, metode yang dilakukan, yaitu melalui sosialisasi kepada masyarakat tentang upaya pencegahan penyebaran Covid-19, Hasil Edukasi Perilaku Hidup Bersih dan Sehat (PHBS) di masa adaptasi kebiasaan Baru di kelurahan kampung baru memberikan dampak positif bagi masyaratkat yang membuat masyarakat memahami tentang PHBS sebagai salah satu tindakan Pencegahan Penularan Covid-19 Pada kelompok Masyarakat yang sangat penting untuk terus di lakukan sehingga masyarakat memiliki kesadaran bersama dan memiliki pengetahuan tentang pentingnya bersama-sama untuk Tetap menjalankan kebiasaan baru( mencucui tangan \& membiasakan menggunakan masker) di masa adaptasi kebiasaan baru
\end{abstract}

Kata kunci: edukasi, prilaku hidup bersih dan sehat, Covid-19

\begin{abstract}
Clean and healthy living behavior or PHBS is an effort to strengthen the culture of a person, group or community so that they care and prioritize health to create a higher quality life. In an effort to prevent the spread of the Covid-19 pandemic, the community has a very important role. Kampung Baru Village is part of the working area of the Malawei Health Center in Sorong City whose area has positive Covid-19 patients. From a report from the West Papua Provincial Health Office, the working area of the Malawei Health Center in Sorong City has 26 positive confirmed COVID-19 cases with 1 person dying. )) during the new adaptation period in the new village village of Sorong city, the method used was through socialization to the community about efforts to prevent the spread of Covid-19, Results of Education for Clean and Healthy Life Behavior (PHBS) during the adaptation period of new habits in the new village village. positive for the community who makes the public understand about PHBS as one of the measures to prevent the transmission of Covid-19 In community groups, it is very important to continue to do so so that people have common awareness and have knowledge about the importance of working together to keep practicing new habits. an \& learn to use a mask) in the period of adapting to new habits
\end{abstract}

Keywords: education, clean and healthy lifestyle, Covid-19

\section{PENDAHULUAN}

Perilaku hidup bersih dan sehat atau PHBS adalah upaya untuk memperkuat budaya seseorang, kelompok maupun masyarakat agar peduli dan mengutamakan kesehatan untuk mewujudkan kehidupan yang lebih berkualitas. Dalam usaha pencegahan penyebaran pandemi Covid-19 ini, Masyarakat memiliki peran yang sangat penting. Peran tersebut antara lain aksi 
preventif dan promotive seperti edukasi, pemantauan dan pencegahan berbasis komunitas. Perilaku hidup bersih dan sehat di masyarakat dan berbagai upaya kesehatan masyarakat lainnya sesuai dengan kondisi di wilayah masing- masing juga perlu disosialisasikan. [1]

Pembinaan PHBS juga merupakan bagian dari pengembangan desa dan kelurahan siaga aktif. Keputusan Menteri kesehatan nomor 1529/ Menkes/ SK/X/2010 tentang pedoman umum pengembangan desa dan kelurahan siaga aktif menyatakan bahwa masyarakat di desa atau keluragan siaga aktif wajib melaksanakan PHBS. Dalam usaha pencegahan penyebaran pandemi Covid-19 ini, pemahaman PHBS dan Kebiasaan PHBS memiliki peran yang sangat penting dalam preventif dan promotive seperti edukasi, pemantauan dan pencegahan berbasis komunitas dalam memutus rantai penyebaran Covid-19.Total kasus seluruh dunia terkonfirmasi positif corona periode tanggal 7 Oktober 2020 tercatat 35.858 .601 ribu orang, pasien sembuh 25.00.569 juta orang, dan meninggal dunia berjumlah 33.219 ribu orang[2]. Data terbaru dari tim gugus tugas covid-19 Di Indonesia, kasus positif mengalami peningkatan yang sangat signifikan yaitu mencapai 315.714 orang terkonfimasi positif COVID-19 dengan 11.472 kematian dan 20.291 sembuh per tanggal 14 juli 2020. Ini menunjukan bahwa penyebaran penyakit ini masih terus berlangsung sehingga memerlukan tindakan pencegahan secepat mungkin [3].

Penerapan PHBS sangat dianjurkan kepada seluruh masyarakat di Indonesia meskipun ada atau tidaknya wabah Covid19. Hal ini dikarenakan menjaga imunitas tubuh sangat penting agar tubuh tetap sehat dan terhindar dari penyakit. Akan tetapi, masih sangat banyak masyarakat Indonesia yang belum paham akan pentingnya pola hidup yang sehat. Terutama pada masyarakat kalangan anak-anak muda yang masih harus dalam pendampingan. Penerapan PHBS dapat dilakukan dengan melakukan pembiasaan seperti menjaga kebersihan lingkungan, olahraga teratur, dan mengonsumsi makanan bergizi. Pemberdayaan masyarakat dalam upaya penerapan PHBS sangat penting untuk dilakukan, karena langkah awal untuk memulai kebiasaan ini dimulai dari rumah tangga atau keluarga [4].

Salah satu cara yang bisa dilakukan untuk mencegah virus Covid-19 adalah dengan menerapkan perilaku Pola Hidup Bersih dan Sehat (PHBS) di mana dalam penerapannya harus dilakukan oleh semua lapisan dimulai dari yang terkecil yaitu individu di dalam setiap keluarga. PHBS memiliki banyak manfaat seperti membuat setiap anggota keluarga menjadi sehat dan tidak mudah sakit, anak tumbuh sehat dan cerdas, badan fit saat bekerja, mampu mencegah dan menanggulangi masalahmasalah kesehatan, serta berbagai manfaat lainnya. Oleh karena pentingnya penerapan PHBS maka disarankan bagi seluruh lapisan agar berturut serta dalam mewujudkannya. Pandemi ini adalah masalah bersama dan tentu harus diselesaikan bersamasama dengan cara mencegahnya sehingga kasus terkonfirmasi dapat mendekati titik 0 sehingga tidak ada lagi penyebaran hingga pada akhirnya Indonesia bisa menang melawan pandemi ini [5].

Wilayah Provinsi Papua Barat tercatat 2.544 orang kasus terkonfirmasi positif,1.386 orang telah sembuh dan 59 orang meninggal dunia periode 7 oktober 2020. Untuk wilayah kota Sorong tercatat terdapat 8 kasus yang terkonfirmasi PCR positif, Kelurahan Kampung Baru merupakan bagian dari wilayah kerja Puskesmas Malawei di Kota Sorong yang wilayahnya memiliki pasien positif Covid-19. Dari laporan Dinas Kesehatan Propensi Papua Barat, wilayah kerja Puskesmas Malawei Kota Sorong terdapat 26 Kasus COVID-19 yang terkonfirmasi positif dengan 1 orang meninggal [6]Berdasarkan hal tersebut maka Kami melakukan Pengabdian di kelurahan kampung baru kota sorong dan terus mengupayakan pencegahan di wilayah kerja kampung Baru .

\section{METODE}

Metode yang dilakukan, yaitu melalui sosialisasi kepada masyarakat upaya pencegahan penyebaran Covid-19 dengan beberapa cara berikut:

a. Peserta Peserta dalam pengabdian masyarakat ini adalah masyarakat yang berdomisili di wilayah kerja kelurahan kampung Baru Kota Sorong.

b. Lokasi dan Waktu Pelaksanaan 
Lokasi Kegiatan Edukasi telah di laksanakan di Aula Kantor Kelurahan Kampung baru Kota sorong. kegiatan Berlangsung Dua kali di tanggal 19 Agustus 2020 \& 16 September 2020, Pukul 09.00- 12.00 WIT. Kegiatan Edukasi di lakukan dengan membagi masyarakat dan menyesuikan dengan kapasitas ruangan aula selama masa pandemic

c. Prosedur Pelaksanaan

Prosedur pelaksanaan dilakukan dengan cara memberikan edukasi terhadap Masyarakat Kampung Baru dengan metode ceramah, sehingga Masyarakat mengerti dan memahami pentingnya pencegahan COVID-19 terus dilakukan. Pengabdian pada masyarakat ini dilaksanakan untuk menambah pengetahuan terhadap Masyarakat dan diharapkan dapat Memutus Rantai penyebaran COVID-19, Membantu Masyarakat Menjaga Pola hidup bersih dan sehat, Membuat Masyarakat terbiasa beradaptasi dengan kebiasaan baru

d. Solusi Permasalahan

Solusi permasalahan yang dilakukan yaitu mengajarkan kepada Masyarakat tentang pentingnya Mencuci tangan \& menggunakan Masker di masa adaptasi kebiasaan baru.

e. Luaran Dan Target Capaian

Target luaran dari kegiatan ini adalah Tercapainya Tujuan Pengabdian dimana masyrakat mampu menerapkan pola hidup bersih dan sehat dimasa pandemi \& Laporan Pengabdian Masyarakat yang dapat di baca oleh masyarakat luas

\section{HASIL DAN PEMBAHASAN}

Kegiatan Edukasi PHBS ini telah di laksanakan di Aula Kantor Kelurahan Kampung baru Kota sorong. kegiatan Berlangsung Dua kali di tanggal 19 Agustus 2020 kami melakukan edukasi kepada pihak kelurahan, kader \& beberapa masyarkat \& tanggal 16 September 2020 kami kembali mengedukasi dengan media lukisan di dinding dan pembagian bingkisan yang di wakili oleh masing masing kader, kegiatan ini berjalan karena kami melakukan kerja sama lintas sector untuk mengupayakan terjadinya gerakan pencegahan bersama-sama. Kegiatan Edukasi di lakukan dengan tetap menyesuikan kapasitas ruangan aula ataupun suasana kantor kelurahan selama masa pandemic. Berikut terdapat beberapa foto yang berhasil didokumentasikan pada saat kegiatan berlangsung:

a. Lokasi Edukasi perilaku hidup dan sehat (phbs) di masa adaptasi kebiasaan baru di kelurahan kampung baru kota sorong

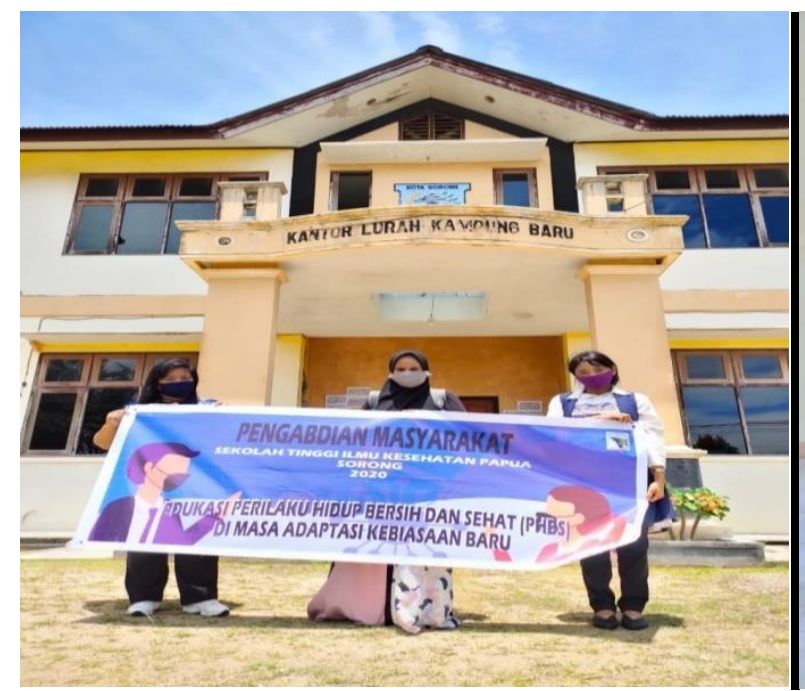

(a)

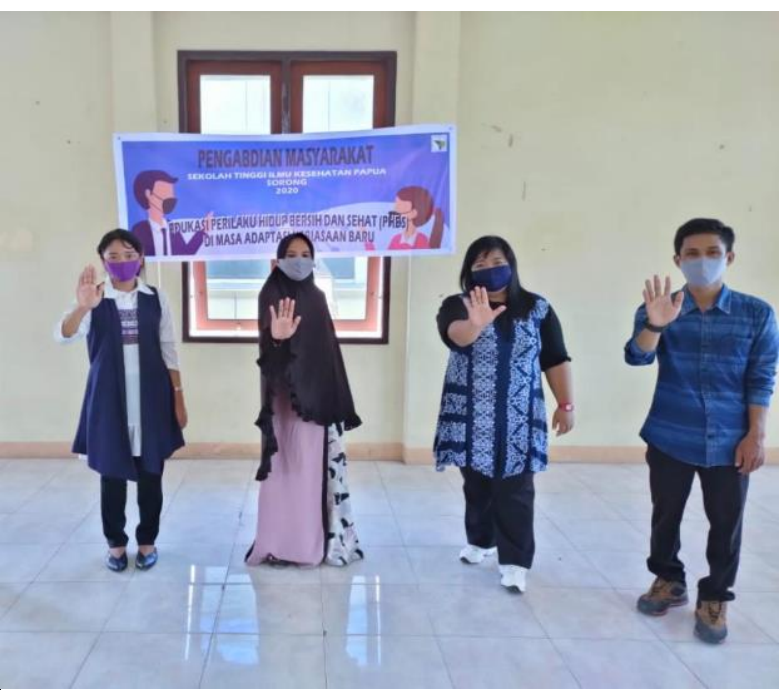

(b)

Gambar 1. Kontor LurahKampung Baru(a) dan (b) 
b. Bahan Materi Edukasi perilaku hidup dan sehat (phbs) di masa adaptasi kebiasaan baru di kelurahan kampung baru kota sorong
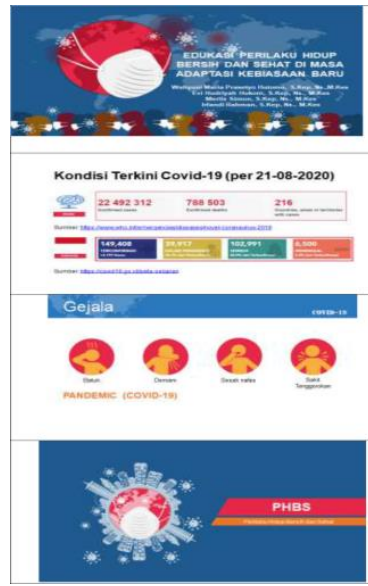

(a)

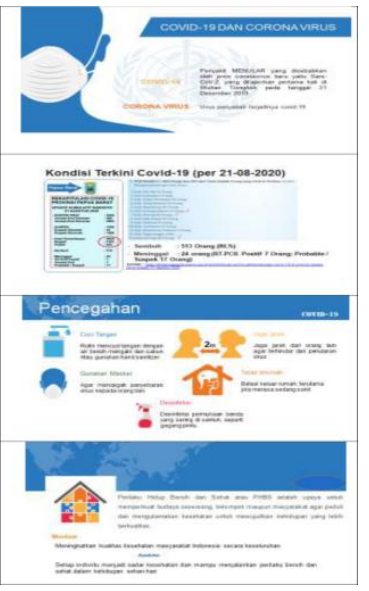

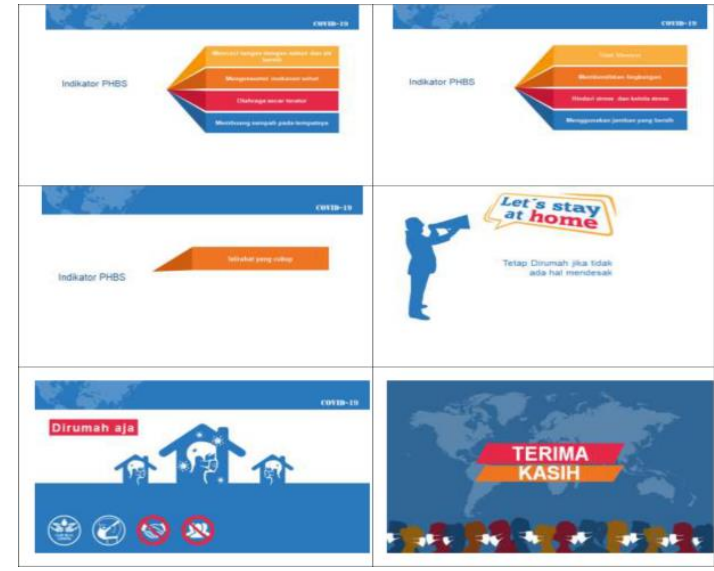

(b)

Gambar 2. Materi Edukasi (a) dan (b)

c. Pemberian Edukasi

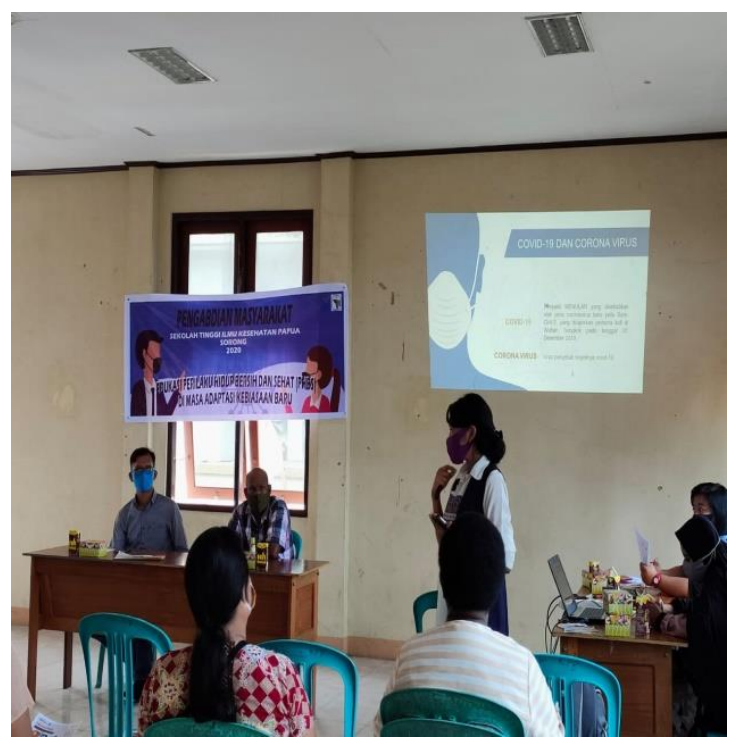

(a)

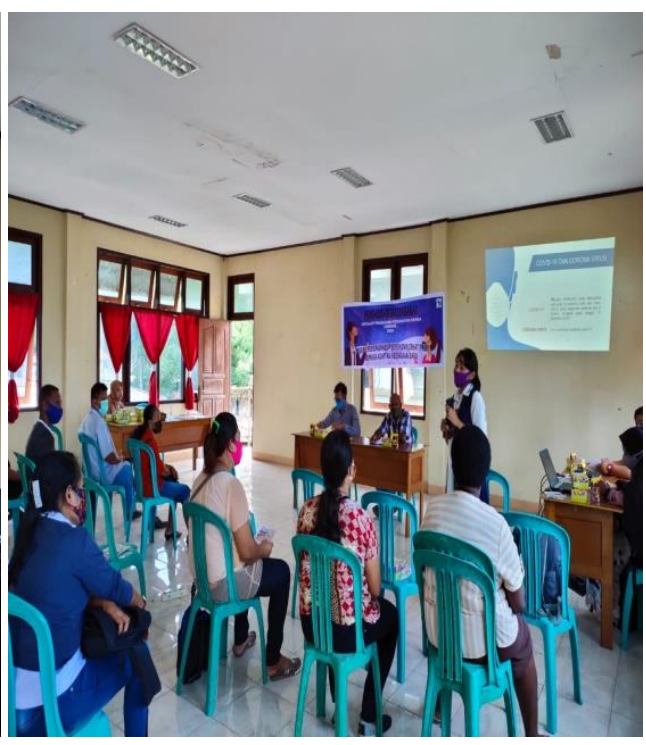

(b)

Gambar3. (a) dan (b) Edukasi

Covid-19 adalah penyakit menular yang disebabkan oleh coronavirus, coronavirus merupakan keluarga besar virus yang menyebabkan penyakit pada manusia dan hewan. Pada manusia biasanya menyebabkan penyakit infeksi saluran pernafasan, mulai flu biasa hingga penyakit yang serius seperti Middle East Respiratory Syndrome (MERS) dan Sindrom Pernapasan Akut Berat/Severe Acute Respiratory Syndrome (SARS) (7).

Sever Acute Respiratory syndrome Coronavirus-2 (SARS-CoV-2) merupakan Coronavirus, jenis baru yang menyebabkan epidemi, dilaporkan pertama kali di Wuhan Tiongkok pada tanggal 31 Desember 2019. Analisis isolat dari saluran respirasi bawah pasien tersebut menunjukkan penemuan Coronavirus tipe terbaru yang diberi nama oleh WHO Covid-19. Pada tanggal 11 februari 2020 WHO memberi nama penyakitnya menjadi (8). 


\section{d. Pembagian Bingkisan}

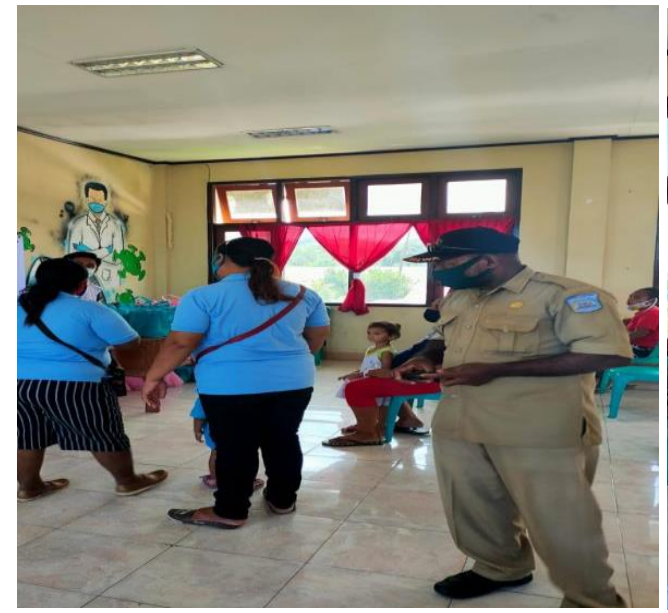

(a)

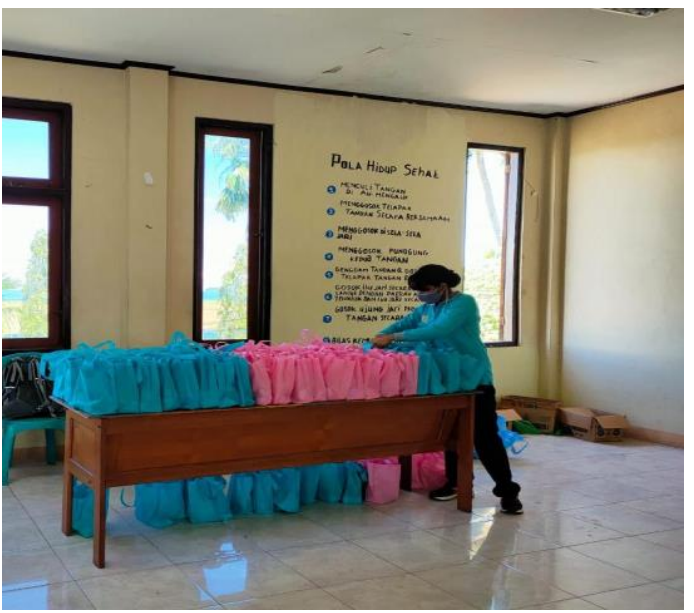

(b)

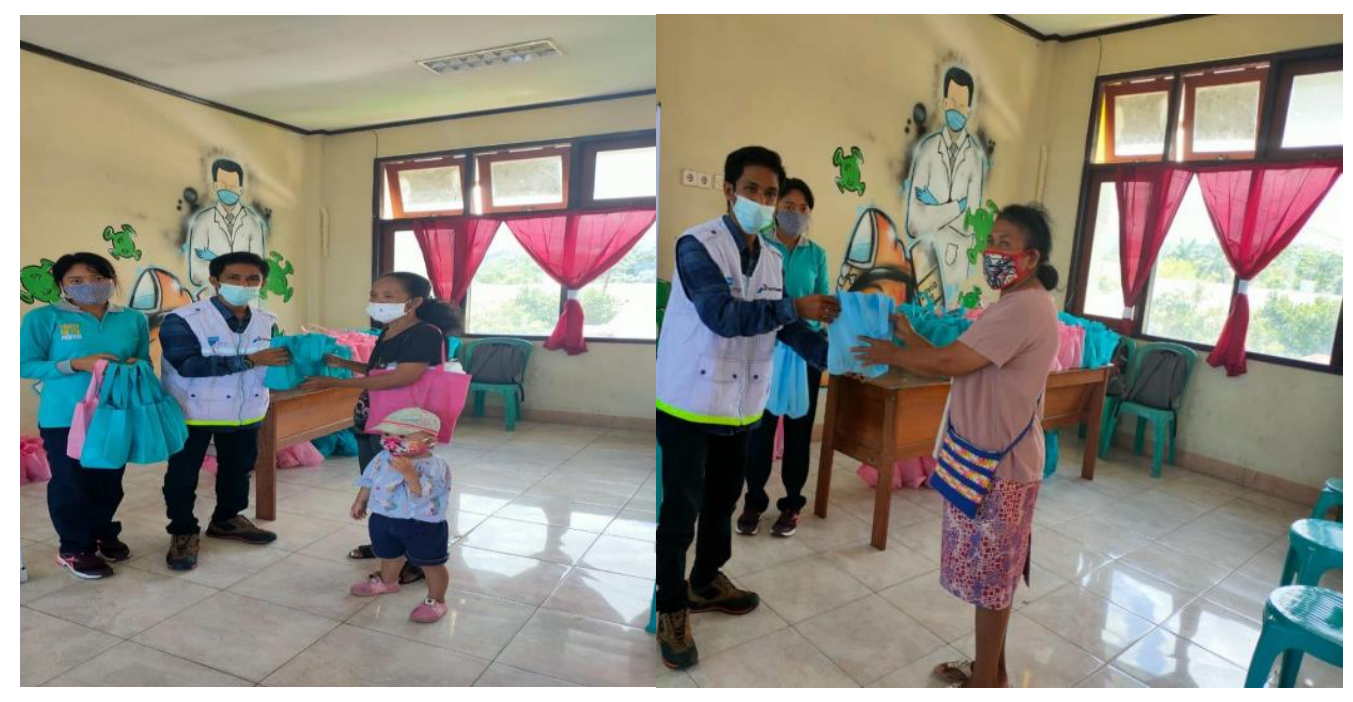

(c)

(d)

Gambar 4. (a), (b), (c) dan (d) Pembagian Bingkisan

Program PHBS adalah upaya untuk memberikan pengalaman belajar bagi perorangan, kelompok dan masyarakat dengan cara membuka jalur komunikasi, memberikan informasi dan melakukan edukasi guna meningkatkan pengetahuan, sikap dan perilaku melalui pendekatan advokasi, bina suasana dan melakukan gerakan pemberdayaan masyarakat sehingga dapat menerapkan cara-cara hidup sehat dalam rangka menjaga, memelihara, melindungi, dan meningkatkan kesehatannya(9).

kami dosen ilmu keperawatan sekolah tinggi limu kesehatan papua melakukan kegiatan edukasi perilaku hidup dan sehat (phbs) di masa adaptasi kebiasaa baru di kelurahan kampung baru kami menyadari negara indonesia bahkan seluruh dunia mengalami dampak dari pandemi covid-19, begitu juga dengan kawasan timur indonesia. tahun yang tidak mudah untuk kita semua akan tetapi selalu ada upaya yang bisa kita lakukan untuk melalui situasi ini dan membuat kita tidak menjadi patah semangat dalam berkarya, bangkit dari keterpurukan. indonesia bisa melewati ini dengan kesatuan bersama yaitu dukungan semua pihak baik pemerintah pusat, daerah dan personal.

Sejalan dengan harapan pemerintah Indonesia dan masyrakat luas di Masa pandemic maka program edukasi PHBS kami lakukan sebagai salah satu usaha untuk membantu pemerintah Indonesia diwilayah timur Indonesia menurunkan angka kejadian Covid-19, 
membangun kerja sama lintas sector untuk sama-sama melakukan pengabdian masyarakat guna tercapainya tujuan bersama untuk terus mempertahakan pola hidup bersih dan sehat yang dapat membantu memutuskan mata rantai penyebaran covid di kota sorong

\section{KESIMPULAN}

Pemberian Edukasi Perilaku Hidup Bersih dan Sehat (PHBS) di masa adaptasi kebiasaan Baru di kelurahan kampung baru sebagai salah satu tindakan Pencegahan Penularan Covid-19 Pada kelompok Masyarakat sangat penting untuk terus di lakukan sehingga masyarakat memiliki kesadaran bersama dan memiliki pengetahuan tentang pentingnya bersama-sama untuk Tetap menjalankan kebiasaan baru ( mencucui tangan \& membiasakan menggunakan masker) di masa adaptasi kebiasaan baru.

\section{UCAPAN TERIMA KASIH (Bila Perlu)}

Penulis mengucapkan terima kasih kepada Ketua Sekolah Tinggi Ilmu Kesehatan Papua, Kepala Kelurahan Kampung Baru, tokoh masyarakat di kelurahan kampung baru, yang secara bersama sama telah memberi dukungan (lintas sektor) terhadap pengabdian ini.

\section{DAFTAR PUSTAKA}

[1] Kemenkes RI, Hindari Lansia dari Covid-19, http://www.padk.kemkes.go.id/article/read/2020/04/23/21/hindari-lansia-daricovid-19.html. Diakses pada tanggal 23 april 2020, 2020

[2] WHO, Pertanyaan dan Jawaban terkait Coronavirus. https://www.who.int/indonesia/news/novel-coronavirus/qa-for-public,2020

[3] Satuan Tugas Penanganan Covid-19, Perubahan Istilah Kasus Covid-19.

https://covid19.go.id/edukasi/masyarakat-umum/perubahan-istilah-kasus-covid-19. Diakses pada tanggal 3 september 2020, 2020

[4] M. F. Natsir, "Perilaku Hidup Bersih dan Sehat (PHBS) pada Tatanan Rumah Tangga Masyarakat Desa Parang Baddo", Jurnal Nasional Ilmu Kesehatan (JNIK) LP2M Unhas, Vol 1, no 3, 2019

[5] H. D. Mulyadi dkk., "Pentingnya Penerapan Phbs Dalam Menghadapi Pandemi Covid-19 Di Lingkungan Masyarakat, https://kkn.unnes.ac.id/lapkknunnes/32004 31741010046 Kelurahan\%20 20200927 072920. 2020

[6] Profil Kesehatan Provinsi \& Kabupaten/Kota. https://dinkes.papuabaratprov.go.id/profil, 2020

[7] Keputusan Menteri Dalam Negeri Nomor 440-830 Tahun 2020 Tentang Pedoman Tatanan Normal Baru Produktif dan Aman COVID19 https://covid19.go.id/p/protokol/keputusan-menteri-dalam-negeri-nomor-440-830tahun-2020

[8] Pedoman Tatalaksana COVID-19 edisi https://www.papdi.or.id/pdfs/938/Pedoman\%20Tatalaksana\%20COVID19\%20edisi\%202.pdf, 2020

[9] A. Yurianto, "Pedoman Pencegahan dan Pengendalian Coronavirus Disease (Covid-19)", Kemeterian Kesehatan RI Direktorat Jendral Pencegahan dan Pengendalian Penyakit (P2P), Jakarta 2020 